\title{
Asymptomatic bacteriuria among elderly and middle-aged rural community-dwellers in South-Western Nigeria
}

This article was published in the following Dove Press journal:

Infection and Drug Resistance

8 July 2013

Number of times this article has been viewed

\author{
OA Olowe' \\ OB Makanjuola' \\ KO Olabiyi' \\ PO Akinwusi ${ }^{2}$ \\ CO Alebiosu ${ }^{2}$ \\ MA Isawumi ${ }^{3}$ \\ MB Hassan ${ }^{3}$ \\ EO Asekun-Olarinmoye ${ }^{4}$ \\ WO Adebimpe ${ }^{4}$ \\ TA Adewole ${ }^{5}$ \\ 'Department of Medical Microbiology \\ and Parasitology, ${ }^{2}$ Department \\ of Medicine, ${ }^{3}$ Department of \\ Ophthalmology, ${ }^{4}$ Department of \\ Community Medicine, ${ }^{5}$ Department \\ of Biochemistry, College of Health \\ Sciences, Osun State University, \\ Osogbo, Osun State, Nigeria
}

Correspondence: OB Makanjuola Department of Medical Microbiology and Parasitology, College of Health Sciences, Osun State University, PMB 4494, Osogbo, Osun State, Nigeria Email funmifemi@yahoo.com

\begin{abstract}
Asymptomatic bacteriuria in elderly individuals has been well described in institutionalized settings, but to a lesser extent in the community. The purpose of this study was to determine the pathogens responsible for asymptomatic bacteriuria in elderly and middle-aged individuals in Alajue-Ede, South-Western Nigeria, and to identify any associated factors. Mid-stream urine samples were collected from apparently healthy elderly and middle-aged volunteers who were participating in community health screening. Samples were processed and bacterial isolates were identified following standard procedures. In total, 128 volunteers (48 men, 76 women) participated in the study. Twenty-eight $(22.6 \%)$ urinary pathogens were isolated, comprising Klebsiella species in five (17.9\%), Pseudomonas aeruginosa in one (3.6\%), Escherichia coli in 19 (67.9\%), and Proteus species in three (10.7\%) cases. Women were identified as being at higher risk of asymptomatic bacteriuria, and the prevalence also increased with increasing age in men. The elderly in this community have a high prevalence of asymptomatic bacteriuria, and screening for comorbid medical conditions may be of benefit.
\end{abstract}

Keywords: asymptomatic bacteriuria, urinary pathogens, elderly, urinary tract infection

\section{Introduction}

Urinary tract infections (UTIs) are common and require treatment with antibiotics. ${ }^{1}$ Asymptomatic bacteriuria is defined as significant bacteriuria without symptoms of UTI. Significant bacteriuria has been defined as the presence of $1 \times 10^{5}$ or more bacteria per milliliter of voided mid-stream urine. ${ }^{2}$

Asymptomatic bacteriuria is common, with varying prevalence according to age, gender, sexual activity, and the presence of genitourinary abnormalities. Several categories of people are reported to be at higher risk, including the elderly, pregnant women, and those with diabetes, particularly women. ${ }^{3}$ Among the elderly, those in institutionalized settings such as long-term care facilities and hospitals have a higher prevalence of asymptomatic bacteriuria than those living in the community. ${ }^{4,5}$ Therefore, interest in asymptomatic bacteriuria has shifted from the general population to these groups of individuals. ${ }^{6}$ The prevalence varies from $2 \%$ to $10 \%$ in pregnancy and from $15 \%$ to $50 \%$ in the elderly in long-term care facilities. 5,7

There has been controversy and conflicting reports as to the significance and benefits of treating individuals with asymptomatic bacteriuria. ${ }^{4,8}$ Significant asymptomatic bacteriuria has been described as an important cause of pyelonephritis and Gramnegative septicemia among predisposed individuals, such as diabetics. ${ }^{9}$ Asymptomatic bacteriuria is also believed to be harmful in pregnant women, men or women undergoing invasive genitourinary procedures, and renal transplant recipients. In these groups, 
adverse outcomes can be prevented using antimicrobial drug therapy and studies have shown that these groups are also at increased risk of symptomatic UTI. ${ }^{6}$ However, there are doubts as to the benefit of treating asymptomatic bacteriuria in elderly individuals, even in institutionalized settings, despite the risk of symptomatic UTI. ${ }^{6}$

This study was undertaken to determine the prevalence of urinary tract pathogens in older people without symptoms in a community setting and to identify factors associated with asymptomatic bacteriuria in these people.

\section{Materials and methods}

This cross-sectional study in the village of Alajue-Ede, South-Western Nigeria, was part of a community health survey of antibiotic use and resistance on April 2011 during World Health Day. Participants in this study were community-dwellers who were at least 40 years of age. Those aged 40-69 years were regarded as middle-aged and those aged 70 years and older were regarded as elderly. The inclusion criteria was apparent good health and ability to give informed consent. Individuals who had been hospitalized during the previous month were excluded. The majority of participants were of low socioeconomic status. Most were peasant farmers and fishermen, while a small percentage were community traders. A free health care system funded by government helps to support community health in this village. This study was approved by the ethics committee of the College of Health Sciences, Osun State University, Osogbo, Nigeria. Informed consent was obtained from all participants after an adequate explanation of the study.

\section{Procedure}

A semistructured questionnaire was given to all volunteers after obtaining informed consent. Thereafter, mid-stream urine specimens were collected and sent to the microbiology laboratory for microscopy and culture. For isolation of organisms, each urine sample was mixed thoroughly and a standard urine sample was inoculated onto blood agar and MacConkey agar medium. All inoculated plates were incubated aerobically at $37^{\circ} \mathrm{C}$ for 24 hours. Bacteriuria $\geq 1 \times 10^{5}$ colonyforming units $/ \mathrm{mL}$ of urine was regarded as significant bacteriuria. Standard microbiological methods of isolation and identification as outlined by Mackie and McCartney were carefully followed in processing the specimens. ${ }^{10}$

\section{Statistical analysis}

Patient demographic and microbiological data were entered using the standard format. All data were analyzed using Statistical Package for the Social Sciences version 16 software (SPSS Inc, Chicago, IL, USA).

\section{Results}

Twenty-eight (22.6\%) of 124 samples showed significant bacterial growth, comprising seven from 48 women and 21 from 76 men. The most frequent isolate was Escherichia coli ( $\mathrm{n}=19,67.9 \%)$, followed by Klebsiella species $(\mathrm{n}=5$, 17.9\%), Proteus species ( $\mathrm{n}=3,10.7 \%)$, and Pseudomonas aeruginosa (one, $3.6 \%$, Table 1). Table 2 shows the age distribution and prevalence of significant bacteriuria according to gender. The age range was 40 to more than 70 years, and the male to female ratio was $2: 3$. There was a higher prevalence of asymptomatic bacteriuria in elderly subjects than in their younger counterparts.

\section{Discussion}

To the authors' knowledge, this study is one of the few addressing the issue of significant bacteriuria in older individuals and the elderly who are not in institutional care. We found a prevalence of $22.6 \%$, which is much higher than that reported by others for this group of individuals, ie, community-dwellers without overt clinical pathology and not in institutional care. ${ }^{1,7,11}$ However, our finding is quite comparable with what has been described in nursing homes and other long-term care facilities, where a high prevalence of asymptomatic bacteriuria has been be attributed to impaired genitourinary status, instrumentation, and increased use of antibiotics. $^{7,12}$ The prevalence of asymptomatic bacteriuria in our community-based study is also similar to findings for diabetics, as described by Alebiosu et al. ${ }^{13}$ However, ours was a group of apparently healthy individuals who were not taking antibiotics and had no overt evidence of UTI or pathology. This high prevalence could be a result of as yet undetected comorbid medical conditions in these individuals.

Table I Prevalence of bacteriuria and the range of uropathogens recovered from urine of asymptomatic volunteers

\begin{tabular}{llll}
\hline Characteristics & $\begin{array}{l}\text { Male } \\
\text { volunteers } \\
(\mathbf{n}=\mathbf{4 8})\end{array}$ & $\begin{array}{l}\text { Female } \\
\text { volunteers } \\
(\mathbf{n}=\mathbf{7 6})\end{array}$ & $\begin{array}{l}\text { Total } \\
(\mathbf{n}=\mathbf{1 2 4})\end{array}$ \\
\hline $\begin{array}{llll}\text { Bacteriuria status } \\
\quad \text { Significant }\end{array}$ & $7(14.6 \%)$ & $21(27.6 \%)$ & $28(22.6 \%)$ \\
$\quad$ Non significant & $10(20.8 \%)$ & $1 \mathrm{I}(14.5 \%)$ & $21(16.9 \%)$ \\
$\quad$ No growth & $31(64.6 \%)$ & $44(57.9 \%)$ & $75(60.5 \%)$ \\
Bacterial organisms & & & \\
$\quad \begin{array}{l}\text { Escherichia coli } \\
\text { Klebsiella species }\end{array}$ & $5(71.4 \%)$ & $14(66.7 \%)$ & $19(67.9 \%)$ \\
$\begin{array}{l}\text { Proteus species } \\
\text { Pseudomonas aeruginosa }\end{array}$ & $1(14.3 \%)$ & $4(19.0 \%)$ & $5(17.9 \%)$ \\
\hline
\end{tabular}


Table 2 Age distribution and prevalence of significant bacteriuria in male and female volunteers

\begin{tabular}{|c|c|c|c|c|c|c|c|}
\hline \multirow{2}{*}{$\begin{array}{l}\text { Age } \\
\text { (years) }\end{array}$} & \multirow[t]{2}{*}{ Sex } & \multirow{2}{*}{$\begin{array}{l}\text { No of } \\
\text { subjects }\end{array}$} & \multirow{2}{*}{$\begin{array}{l}\text { Significant } \\
\text { bacteriuria } \\
\text { no (\%) }\end{array}$} & \multicolumn{4}{|c|}{ No (\%) of isolates } \\
\hline & & & & E. coli & Klebs spp & Proteus spp & P. aeruginosa \\
\hline \multirow[t]{2}{*}{$40-49$} & $M$ & 8 & $0(0.0)$ & $0(0.0)$ & $0(0.0)$ & $0(0.0)$ & $0(0.0)$ \\
\hline & $\mathrm{F}$ & 22 & $5(22.7)$ & $2(40.0)$ & I $(20.0)$ & $2(40.0)$ & $0(0.0)$ \\
\hline \multirow[t]{2}{*}{$50-59$} & $M$ & 14 & I (7.I) & $I(100)$ & $0(0.0)$ & $0(0.0)$ & $0(0.0)$ \\
\hline & $\mathrm{F}$ & 21 & $7(33.3)$ & $6(85.7)$ & I (I4.3) & $0(0.0)$ & $0(0.0)$ \\
\hline \multirow[t]{2}{*}{$60-69$} & $M$ & 15 & $3(20)$ & $2(66.7)$ & I (33.3) & $0(0.0)$ & $0(0.0)$ \\
\hline & $F$ & 17 & $4(23.5)$ & $4(100.0)$ & $0(0.0)$ & $0(0.0)$ & $0(0.0)$ \\
\hline \multirow[t]{2}{*}{$\geq 70$} & M & 11 & $3(27.3)$ & $2(66.7)$ & $0(0.0)$ & I (33.3) & $0(0.0)$ \\
\hline & $\mathrm{F}$ & 16 & $5(3 \mid .3)$ & $2(40.0)$ & $2(40.0)$ & $0(0.0)$ & I (20.0) \\
\hline
\end{tabular}

It is important to screen such individuals for diabetes which is often found in association with asymptomatic bacteriuria. ${ }^{3}$ Our finding of an almost $23 \%$ prevalence of asymptomatic bacteriuria in older community-dwellers underscores the need for regular health screening, especially in high-risk groups.

$E$. coli was found to be the leading urinary pathogen in this study, and was documented in $66.7 \%$ and $71.4 \%$ of women and men, respectively. Becker et al, Drucker et al, and Olusanya and Olutiola have reported that the most common urinary pathogens causing asymptomatic bacteriuria are enteric organisms, ie, E. coli and other coliforms. ${ }^{14-16}$ In contrast with this observation, Dada-Adegbola and Muili reported that in their study Klebsiella was the leading urinary pathogen. ${ }^{17}$ Organisms such as Pseudomonas and Proteus were quite rare in this study, unlike in institutional settings where these pathogens are more common, likely because they are not usually acquired in the community. ${ }^{18}$

The results of our study also indicate that the prevalence of asymptomatic bacteriuria is higher in women than in men. This is in agreement with the findings of several earlier studies. $^{7,11}$ This is related to the short course of the female urethra and its proximity to the anorectal region, making it easier for enteric organisms to colonize, ascend, and subsequently attach to the uroepithelium. The prevalence of asymptomatic bacteriuria also appears to increase with increasing age in men, as reflected in a prevalence of $7 \%$ in 50 -year-olds, which increased to $20 \%$ among those in their 60 's then to $31 \%$ in the elderly. It is uncertain why women did not show the same prevalence pattern, despite several reports that prevalence of asymptomatic bacteriuria increases with age, even among women. ${ }^{7,18}$ The picture in men is likely to be attributable to the prostatic enlargement that occurs with increasing age and causes urinary retention. . $^{5,7}$

We also noted that the prevalence of asymptomatic bacteriuria in the middle-aged group was $20.6 \%$ whereas it was $29.6 \%$ in the elderly group. Further investigation did not reveal any statistically significant difference in prevalence between these two age groups despite an initial indication of a significant difference. This might be because of the small size of our study, and further studies are needed to determine whether there is any difference in the prevalence of asymptomatic bacteriuria between middle-aged and elderly adults.

In conclusion, although there is controversy regarding whether to treat asymptomatic bacteriuria in an otherwise healthy adult, we recommend that further investigations be carried out in individuals living in the community setting to determine the cause of this high prevalence of asymptomatic bacteriuria. Underlying condition(s) could require treatment, which might prevent unnecessary morbidity.

\section{Disclosure}

The authors report no conflicts of interest in this work.

\section{References}

1. Colgan R, Nicolle LE, McGlone A, Hooton TM. Asymptomatic bacteriuria in adults. Am Fam Physician. 2006;74:985-990.

2. Rubin RH, Shapiro ED, Andriole VT, Davis RJ, Stamm WE. Evaluation of new anti-infective drugs for the treatment of urinary tract infection. Clin Infect Dis. 1992;15:216-227.

3. Renko M, Tapanainen P, Tossavainen P, Pokka T, Uhari M. Metaanalysis of the significance of asymptomatic bacteriuria in diabetes. Diabetes Care. 2011;34:230-235.

4. Nicolle LE, Bradley S, Colgan R, Rice KC, Schaeffer A, Hooton MT. Infectious Diseases Society of America guidelines for the diagnosis and treatment of asymptomatic bacteriuria in adults. Clin Infect Dis. 2005;40:643-654.

5. Nelius T, Filleur S, Nelson JS. Asymptomatic Bacteriuria: Significance for Different Patient Population, Urinary Tract Infections. Manhattan, NY: Intech; 2011. Available from: http://www.intechopen.com/books/ urinary-tract-infections/asymptomatic-bacteriuria-significance-fordifferent-patient-population. Accessed May 16, 2013.

6. Nicolle LE. Asymptomatic bacteriuria - important or not? N Engl J Med. 2000;343:1037-1039.

7. Rodhe N, Molstad S, Englund L, Svardsudd K. Asymptomatic bacteriuria in a population of elderly residents living in a community setting: prevalence, characteristics and associated factors. Fam Pract. 2006;23:303-307. 
8. Lee S, Kim K, Park Y, Kim Y. Association between asymptomatic urinary tract infection and postoperative spine infection in elderly women: a retrospective analysis study. J Korean Neurosurg Soc. 2010;47:265-270.

9. Kayima JK, Otieno LS, Twahir A, Njenga E. Asymptomatic bacteriuria among diabetics attending Kenyatta National Hospital. East Afr Med J. 1996;73:524-526.

10. Mackie, McCartney. Practical Medical Microbiology, 14th ed. London, UK: Churchill Livingstone; 1996.

11. Varli M, Guruzb H, Arasa S, Yalcina A, Atlia T, Turgaya M. Asymptomatic bacteriuria among the elderly living in the community: prevalence, risk factors and characteristics. Eur Geriatr Med. 2012;3:87-91.

12. Boscia JA, Kobasa WD, Knight RA, Abrutyn E, Levison ME, Kaye D. Epidemiology of bacteriuria in an elderly ambulatory population. Am J Med. 1986;80:208-214.

13. Alebiosu CO, Osinupebi OA, Olajubu FA. Significant asymptomatic bacteriuria among Nigerian type 2 diabetics. J Natl Med Assoc. 2003;95: 344-349.
14. Watts ER, Hancock V, Ong CY, Vejborg RM, Mabbett AN, Totsika M, et al. Escherichia coli isolates causing asymptomatic bacteriuria in catheterized and noncatheterized individuals possess similar virulence properties. J Clin Microbiol. 2010;48(7):2449-2458.

15. Roos V, Ulett GC, Schembri MA, Klemm P. The asymptomatic bacteriuria Escherichia coli strain 83972 outcomes Uropathogenic E. coli strains in human urine. Infect Immun. January 2006;74(1):615-624.

16. Olusanya $\mathrm{O}$, Olutiola PO. Studies on bacteriuria in patients and students in Ile-Ife, Nigeria. West Afr J Med. 1984;303:177-182.

17. Dada-Adegbola HO, Muili KA. Antibiotics susceptibility pattern of urinary tract pathogens in Ibadan, Nigeria. Afr J Med Med Sci. 2010;39: 173-179.

18. Ariathianto Y. Asymptomatic bacteriuria - prevalence in the elderly population. Aust Fam Physician. 2011;40:805-809.
Infection and Drug Resistance

\section{Publish your work in this journal}

Infection and Drug Resistance is an international, peer-reviewed openaccess journal that focuses on the optimal treatment of infection (bacterial, fungal and viral) and the development and institution of preventive strategies to minimize the development and spread of resistance. The journal is specifically concerned with the epidemiology of antibiotic

\section{Dovepress}

resistance and the mechanisms of resistance development and diffusion in both hospitals and the community. The manuscript management system is completely online and includes a very quick and fair peerreview system, which is all easy to use. Visit http://www.dovepress.com/ testimonials.php to read real quotes from published authors. 